\title{
Bankers on Board, Banks as Shareholders and Firm's Performance: Case of the Tunisian Listed Companies
}

\section{Affes $\mathrm{H}$ and Hakim $\mathrm{NH}^{*}$}

Lecturer at the Faculty of Sciences, Faculty of Economics and Management of Sfax, University of Sfax, Tunisia

\begin{abstract}
Unlike the Anglo-Saxon countries, where business financing is made through the financial markets, Tunisian banks play a more important role than the financial markets in funding the firms. In addition to their function as lenders, they can participate in the capital of companies and/or serve on their boards. Our results on a sample of 14 listed companies on the Tunisian Stock Exchange (STE) during the 2003/2009 period show that banks play an important role in the governance of the Tunisian firms and affect their performance. Based on this sample, we performed regressions of these two governance variables (banking participation in the firms' equity and boards) on the firms' accounting and stock performance. The obtained results show that, firstly, the banking investment in the firms' share capital has a negative impact on the accounting performance measured by the ROA and the ROE and positively on the stock market performance (Tobin's $Q$ and Marris) and, secondly, the banking presence in the board of directors has both a positive and negative impact on the accounting performance on the stock market performance.
\end{abstract}

Keywords: Bankers on board; Banks as shareholders; Firm's Performance; Anglo-Saxon

\section{Introduction}

Nowadays, the corporate finance researches attach great importance to the role of banks in the management of enterprises [13]. In fact, companies resort to banking indebtedness. The nature of the relationship between banks and enterprises depends on the country and the existing regulations. Unlike Germany and Japan, where financing takes place via banks, the Anglo-Saxon financial markets play an important role in the funding and control of companies. German companies maintain long term relationships with a Bank called "Hausbank". A fundamental characteristic of these banks is their participation in the companies' capital and funding them Moreover, the Japanese Keiretsu system enables banks to become shareholders and members in the Board of Directors. The bank ownership is a very widespread phenomenon in the Japanese banking systems and the continental Europe. The theory recognizes the ability of the bank holdings on the liabilities of big businesses to improve the control system of the leaders. Moreover, the presence of banks in the capital of companies improves the quality of information they have, which leads to a more efficient control of the investment activities. The banking participation in the companies' capital enables them to acquire data related to the internal functioning of the company, the sector and competition. This piece of information does not exist in the accounting and financial documents which are usually possessed by banks.

Unlike the studies dealing with the effect of composition of the Board of Directors and the structure of property on performance, the ones conducted about the effect of the presence of banks in both the Board of Directors and in the structure of property on performance are few. Indeed, the scarcity of studies has led to the present research.

The agency theory assumes that there are conflicts of interest between the shareholders and the creditors. The control exercised by the banks on companies helps reduce the agency costs [4]. Therefore, according to the assumption of control, the presence of the banks in the Board of Directors reduces the agency costs and improves the company's value. On the other hand, under the assumption of the agency costs of debt-equity, the banks' presence in the Board of Directors negatively impacts the company's value. On the other hand, according to the assumption of the agency costs of debt-equity, the banks' presence in the Board of Directors negatively effects on the company's value. Bubna and Radhakrishnan [5] showed that there are information asymmetries between the shareholders and the creditors. According to this hypothesis, the presence of banks in the board of directors reduces the information asymmetries between the firms and the creditors and consequently improves the companies' value.

The existence of conflicts of interest between the shareholders and the creditors is reduced by a set of internal and external mechanisms. The board of directors and ownership structure are two alternative mechanisms of governance and control. Besides these two internal governance mechanisms, the presence of banks in the board of directors and ownership structure are also two governance mechanisms since this presence is associated with a reduction of the agency costs due to the conflicts of interest between the shareholders and the creditors.

The practice of the banks' participation in the firms' capital depends on the country considered. Actually, in France, for example, banks are under no obligation to participate in the firms' capital. However, the American legislation and more particularly the Glass-Steagall Act (1933) prevents banks from participating in the firms' capital. Recently, the American legislation, through the Gramm-Leach- Bliley Act, has given commercial banks the opportunities to participate in the capital of firms. Besides, Germany, which encourages the banks' participation in the companies' capital, introduced some restrictions which were discussed in the Bundestag (1977). A very recent study has revealed that the Monopoly Commission limited the banks' participation to the amount of $5 \%$ of the companies' capital. The banking regulations in

*Corresponding author: Hakim $\mathrm{NH}, \mathrm{PhD}$, Faculty of Economics and Management of Sfax, Lecturer at the Faculty of Sciences, University of Sfax, Tunisia, Tel: 21674244423; E-mail: nourchenehamza@gmail.com

Received March 13, 2016; Accepted March 21, 2016; Published March 31, 2016

Citation: Affes H, Hakim NH (2016) Bankers on Board, Banks as Shareholders and Firm's Performance: Case of the Tunisian Listed Companies. J Bus Fin Aff 5: 180. doi:10.4172/2167-0234.1000180

Copyright: ( 2016 Affes $\mathrm{H}$, et al. This is an open-access article distributed under the terms of the Creative Commons Attribution License, which permits unrestricted use, distribution, and reproduction in any medium, provided the original author and source are credited. 
Tunisia, and more specifically article 21 of Act No. 2001-65 of 10 July 2001 about the credit institutions, stipulate that a credit institution may hold directly or indirectly more than $30 \%$ of the capital of the same company.

\section{Literature Review}

\section{Banks' participation in the firms' capital in the different theories}

Jiang et al. state that the presence of the banks as creditors and shareholders is explained by both the agency and the information asymmetry theories [3]. The banking representation in the companies' capital is beneficial insofar as it helps reduce the conflicts of interest and the information asymmetries between the shareholders and the creditors.

In the agency theory: Being at the same time lenders and shareholders, banks face an apparent conflict of interest and may therefore give their own interests at the expense of the interests of the ordinary shareholders. This apparent conflict between banks and shareholders generates agency costs. However, Petersen and Rajan stipulates that the banks' participation in the capital helps reduce the agency costs when banks act in the interests of the shareholders [6]. Furthermore, he asserts that their presence in the capital improves the flow of information between companies and banks, which therefore reduces the conflicts of interest between the shareholders and the creditors.

Apart from the benefits of the agency cost reduction of the bank shareholding, banks buy the companies' shares when they have the private information that makes them believe that these companies' shares are undervalued. In fact, when banks possess such inside information, they will have the opportunities and incentives to acquire the undervalued shares of these firms to generate capital gains.

Most of the studies point out that the reduction of the agency problems between banks and firms explain the positive relationship between the bank shareholding and the companies' performance. In accordance with this hypothesis, Flath [7] states that the largest creditors in the keiretsu member companies, highly indebted and with strong growth prospects have majority stakes.

Gonzalez states that a bank's decision to raise or reduce the banking debt about the acquisition of capital is operated by the market to know which of the two potential motivations explains the banks' participation in the companies' capital [8]. The author shows that the market explains the banks' participation in the capital together with the reductions of the banking debts by the rise of the agency costs. However, both the banks' stake and the rising banking debt are considered by the market as elements indicating that the bank possesses positive information about the company's prospects. According to this explanation, the companies' abnormal stock returns regarding the announcement of the banks' participation in the capital differ depending on the decision about the banking debt.

The acquisition of the shares by the banks is a mechanism to reduce agency costs. In other words, this acquisition of shares of firms by banks or the participation of the banks in the capital of companies is the result of increases in the costs of Agency Gonzalez [8]. According to this principle, a fall of profitability or a rise of the risk raises the agency costs between the bank and the firms and justifies the involvement of the banks in the capital [7].

Gonzalez states that it is impossible to predict the reaction of the share price when banks participate in the companies' capital when the prospects are unfavorable (lower profitability and/or higher risk under the assumption of the agency costs) or better (higher profitability and/ or lower risk under the assumption of the information asymmetry) [8].

Jiang W, Li K, Shao P stipulate that if the origin of the banks' participation in the capital is a rise of the agency costs, then banks may reduce their debt to firms because of these costs [3]. Actually, high agency costs that emerge when companies announce they are insolvent cause an increase of the capital share held by banks and reduce their debt in companies [9-11].

Gonzalez F expects some financial exchange making it possible to reduce the agency costs between the shareholders and the creditors. Moreover, he found that, in countries where banks' participation in the capital is permitted, banks buy the companies' shares and reduce debts in the defaulting firms if they expect a decline of profitability and/or a rise of the company's risk [8].

The agency theory stipulates that the companies' returns on the shares decline following the announcement of the banking participation in the capital preceded by reductions in banking indebtedness. In fact, Gonzalez F showed that the banks' participation in the capital followed by a decline of the banking debts gives negative information to the market about the companies' profitability and risk [8].

Jiang et al. Suggest that the presence of the creditors in the ownership structure enables them to control the leaders and prevents the leaders and/or the large shareholders from taking action which expropriate the creditors [3]. Kalyani examined the effect of the strong relationship between banks and enterprises on the funding constraints. The conflicts of interest between the shareholders and the creditors are a funding constraint. The author also found that the banking participation in the companies' capital helps eliminate the conflicts of interest between the shareholders and the creditors and consequently reduces the resulting agency costs.

In the information asymmetry theory: Gonzalez stipulates that banks may acquire the shares of undervalued companies where they are better informed about the firms' quality (information asymmetry hypothesis) [8]. Under this assumption, the rise of the expected profitability and/or the reduction of the company's risk explain the banks' participation in the capital of firms, while providing capital gains for banks [12]. In other words, the under-valuation of the companies' shares induces banks to participate in their capital. In fact, any participation in the capital is based on the fact that the bank has positive internal information about the company's future. This assumption therefore expects that the decision by the Bank to acquire shares is linked to the expectations of a greater profitability and/or a lower company's risk [8]. Jiang et al. showed that keeping shares and debts given to creditors provides the shareholders with an informational advantage which helps them to choose the borrowers with a lower default risk [3]. From the capital point of view, the institutions participating in the companies' capital will be more informed than the other shareholders due to their effort and their better access to the leaders.

Taking into account the debt, it appears that the syndicated loans are private mechanisms through which confidential information about the company is revealed to the lenders. The creditors' dual position enables them to acquire more information and look for companies having better credit quality, which will consequently reduce the debt cost. Furthermore, by holding a fraction of the capital in the companies, a bank gets new information about the firms' quality, which will help the companies raise their debt with banks $[6,13]$. On the basis of this theory 
Gonzalez [8] states that the bank which possesses private information about the firm's prospects should participate in the companies' capital so as to get capital gain.

\section{The presence of banks in the board of directors as seen by the various theories}

In the agency theory: The agency theory assumes that there are conflicts of interests between the shareholders and the creditors that can be solved through a set of internal or even external mechanisms among which we can cite the presence of banks in the Board of Directors. Actually, this presence is beneficial since, according to the agency theory, it minimizes the potential conflicts between the shareholders and the creditors. The presence of banks in the Board ensures a better control. The benefits related to the control exercised by the banks on business help reduce the agency costs [4].

Randall and Strahan [4] argue that American banks are board members because they are concerned only by their function as lenders. On the other hand, this study reveals that one third of the American companies have a Board of Directors dominated by a bank suggesting that the benefits associated with the control by banks help reduce or even eliminate the costs generated by the conflicts of interests. Contrary to what exists in Germany and the Japan, this low percentage is due to the protection of the creditors' rights.

Furthermore, Randall and Strahan found a negative relationship between the presence of banks in the companies' boards of Directors and the conflicts of interests between the creditors, among other things, banks and shareholders [4]. Actually, banks are present in the companies' Boards of Directors if the conflicts of interests between the shareholders and the banks are not very important. In fact, to better defend and act in the shareholders' interests, banks expressed interests have interest in joining the Board of Directors. Randall and Strahan argue that the banks must join the Board of Directors to avoid the conflicts of interests that arise between the banks and company's shareholders [4]. However, Byrd and Mizruchi state that the appointment of banks in the Board of Directors goes against the shareholders' interests [14].

The control hypothesis underlines the role the banks' representatives on the Board of Directors in controlling the leaders. According to this control hypothesis, banks generally that lie ahead for the companies' Board of Directors with lots of agency problems. Moreover, on the basis of the control hypothesis, the banks' membership in the Board of Directors reduces the agency costs and improves the company's value.

The hypothesis of the agency costs, debt, and equity underlines the agency problems between the lenders and the shareholders, and the role of the representatives of the banks in the worsening of these problems. The lenders and shareholders have conflicts because of their different choices of risk which are caused by their different payment structures. In fact, while the lenders prefer a lower risk, the shareholders prefer a higher risk. According to this hypothesis, the fact the banks become members of the Board of Directors negatively affects the market value of equity capital and shows a low market capitalization.

In the theory of the information asymmetry: The hypothesis of the information asymmetry focuses on the role of the banks' representatives to collect information on the company and transmit it to the lender who, in turn, reduces the extent of the information asymmetry between the lender and the company and facilitates external financing. This is beneficial for companies which a greater information asymmetry and financial difficulties [5]. In this scenario, firms with large information problems are more likely to have bank representatives on their boards of directors. Moreover, this information asymmetry hypothesis also provides that companies with a bank representative on their boards have fewer financial constraints and a higher value [5].

\section{Banking participation in equity and performance}

Meckling argues that the agency relationship between the shareholders and managers, on the one hand, and between the shareholders and creditors, on the other hand, generates conflicts of interest which involve the agency costs [15]. First, the conflicts between the shareholders and the managers can be reduced by a set of internal and external mechanisms. Then, some researchers state that the conflicts of interest between the shareholders and the creditors are eliminated if banks occupy a dual position as shareholders and creditors $[16,17]$. As a consequence, the presence of banks in the companies ownership structure is a way to reduce the conflicts of interest between the shareholders and the creditors.

The banking control of the managers is very common within the Japanese companies. Moreover, the important disciplinary role exerted by banks is put forward as one of the determining factors of the Japanese firms' efficiency. The Japanese companies, which belong to a "keiretsu", are controlled by the main banks which are at the same time shareholders and creditors Kang, Shivdasani, Kaplan, Minton, Morck, Nakamura showed that the major Japanese banks play a crucial role in corporate governance [18-20]

A great deal of research underlines the relationship between the banks' participation in the capital and the firms' performance. However, the obtained results are contradictory, as some have found a linear relationship while others have demonstrated a nonlinear relationship. Banks play a dual role as they are considered at the same time shareholders and creditors. In fact, this dual role affects their motivation to defend the shareholders' interests and, therefore, the company's value [20]. In Japan, Morck, Nakamura, Shivdasani showed that there is a convex relationship between the banks' participation in the companies' capital and their value [1]. This relationship is negative in the case of low levels of equity participation.

Cable showed the existence of a significant positive relationship between the banks' participation in the capital and the profitability of large industrial companies [21]. Gorton, Schmid, Nibler, Perlitz, Seger found a positive relationship between the control by a bank and performance [22-25]. In fact, they found that banks' participation in the companies' capital improves performance when measured with the ROE. Zoido studied the role of the shareholder banks in the industrial companies and showed that the banks exercise their right of control over the decisions taken by companies [26]. Their control is reflected in the low cost of project funding and in the way in which companies solve their financial problems. Pushner found a positive relationship between banks' equity participation and the efficiency of the Japanese companies [27].

On the other hand, Weinstein and Yafeh studied the effect of stable relationships between banks and companies and found that companies which maintain stable relationships do not get higher profits than those that do not have stable relationships but have the same growth rate [28]. Gorton and Schmid found a positive relationship between the banks' participation in the companies' equity and their performance [29]. Lehmann and Weigand reached the same conclusions as those of Gorton and Schmid except that the first used the ROA as an alternative measure of performance [30]. 
In contrast, in Germany, Weinstein, Chirinko, Kang found a negative relationship between the capital share held by the bank and performance $[28,31,32]$. Moreover, Emmons, Schmid found a roof-shaped relationship (U-shaped) between performance and the percentage of capital held by the bank, which confirms the managerial hypothesis [33].

Using a sample of 142 companies during the period 1999-2002, Palenzuela, Iturriaga, Tejerina found that banks play a crucial role in corporate governance in Spain [34]. In fact, banks not only act as creditors but can grab a share of the capital as they can serve on the Board of Directors. The authors also claim that control through banks has an impact on the companies' performance. Palenzuela, Iturriaga, Tejerina conducted a comparative study on the bank shareholding between companies in which control comes from banks and those in which control is not confined to banks and found that for the first category of companies, the bank shareholding reduces the performance, however, for the second category of companies, the bank shareholding positively affects performance [34].

On a sample of 94 German companies during the 1992/1996 period, Chirinko and Elston found that the relationship between the Bank shareholding and performance is nonlinear [31]. The sample of Gorton and Schmid consists of two sub samples [22]. The first consists of 88 companies and analysis refers to the year 1974. The second sample consists of 66 companies and relates to the year 1985. They use the capital share held by the Bank as a variable representing the ownership structure and the ROA and ROE as alternative measures of accounting performance.

Gorton and Schmid showed that the relationship between the bank shareholding and performance is based on three hypotheses; the alignment of interests, the opposite or the divergent interests and the managerial hypothesis [22]. Each hypothesis can be associated with an infinite number of explanations. The alignment of interest hypothesis assumes that the capital share held by the bank will be positively related to performance. The argument that corresponds to it is that of aligning the shareholders and creditors' interests. The divergence of interest hypothesis predicts that an increase of the share capital held by the bank is associated with a decrease of performance. The divergence of interests between banks and other shareholders explains this inverse relationship. The third assumption is that the relationship between the capital share held by the bank and performance is nonlinear. In fact, performance decreases and then rises again. This assumption is similar to the managerial one supported by Morck and Nakamura or to the one that tested the effect of the managers' capital participation on performance [20].

Jiang et al. [3] Showed that the relationship between the capital shares held by the bank and the ROE is not linear, in other words, it rises then falls. On the other hand, in a study conducted during the 1965/1990 period, Chirinko and Elston [31] found no relationship between the capital share held by a bank and the performance measured by the ROA.

On a sample of Japanese companies, Wenlian studied the impact of bank's main shareholding on the performance during the 1977/1987 period [35]. In this regard, he conducted a comparative study between affiliated and independent firms and found that the former have a lower performance compared to the latter. By examining a sample of Japanese firms over the 1971/1981 period, Nakatani [36] stated that firms which have relationships with banks have a lower profit and growth rate and a lower performance than independent firms.
In affiliated companies or companies belonging to a group, such as Keiretsu, banks act primarily to save the companies in difficult situations [37]. However, in independent companies, the banking role is rather to defend the creditors' interests and not the shareholders'. Gonzalez [8] analyzed the impact of bank's participation in the capital on a sample of companies in Spain over 1992/1998 period and found that firms in which banks participate in the capital show high levels of profitability and low risk levels.

All these empirical studies show that the affiliated companies reported low cash flow and do not guarantee better performance than the independent ones due to the expropriation of the main bank Indeed, Morck et al. [1] showed that the major banks maximize their interests through their presence as shareholders and a creditor in companies.

Nachane et al. [38] found a nonlinear relationship between the participation of the major banks and the firm's performance measured by Tobin's Q. Indeed, at low levels of participation of banks in the capital, an increase of this share lowered performance as measured by Tobin's et al. [39] examined a sample of German companies and found that most of the banking ownership in the capital of companies has a positive effect on the equity value measured by the Market to book ratio. They distinguished between majority-shareholder banks and other banks and found that they both have a positive impact on the performance of large listed companies.

The studies focused on the performance difference between the affiliated and independent firms [28,36,40]. Moreover, Gorton et al. [22] state that the relationship between the banks' participation and firm's performance is based on three assumptions. The first assumption is that of the alignment of the banks' interests with the shareholders'. According to this hypothesis, the relationship between the banking participation in the capital and the firm's performance is positive. The higher this share held by banks is, the more the latter ones use their power and information they have to control the managers and the higher the firms' performance will be:

Hypothesis 1: The relationship between the banking stake in the capital and the firms' performance is on the rise (interest convergence hypothesis or the interest alignment).

The second hypothesis is of the different or opposing interests. In fact, banks' interests do not coincide with the shareholders'. The presence of banks as creditors and shareholders and in front of a noncompetitive capital market, banks act like monopolists which use their power to extract firms' annuity at the expense of the shareholders, which negatively affects the performance.

Hypothesis 2: The relationship between the banking participation in the capital and the firm's performance is falling (hypothesis of conflicting interests)

Hypothesis 3: The relationship between the banking participation in the capital and the firm's performance falls and then rises again (managerial hypothesis)

\section{The banking presence in the board of directors and performance}

A great deal of research has shown a relationship between the presence of the bank in the board of directors and the firms performance. The results were contradictory. Some found a linear relationship while others found the opposite. 
Rosenstein and Wyatt [41] indicated that the proportion of outside directors is positively related to profitability. This positive relationship has an impact on the appointment of a new financial director. The authors add that these outside directors are elected for their expertise. Financial outside directors provide financial security for the business [42-45].

On a sample of 55 Japanese companies, Naohito et al. [46] showed that the presence of banks in the companies' boards of directors helps them better control the leaders. On the other hand, Nachane et al. [38] showed that the presence of banks on the companies' boards of directors has a positive impact on the company's performance due to their expertise.

In the United States, banks do not have the right to participate in the capital of non-financial companies but are often members of the Board of Directors. According to Santos and Rumble [47], the 100 largest US banks control $10 \%$ of the voting rights of the 500 nonfinancial companies of the Standard and Poor's index. They also found that, for some companies of S\&P 500, banks hold more than $20 \%$ of the voting rights.

Randall and Strahan [4] examined the impact of banks as directors and found that US banks are more likely to sit on the boards of stable large-sized firms which have high proportions of tangible assets and use less short-term funding. On a sample of Japanese firms over the period 1981-1987, Morck and Nakamura [20] examined the impact of the presence of banks in the companies' boards of directors on the firm's value and found that their appointment does not maximize the value.

On a sample of German companies, Dittmann et al. [2,48] found a negative relationship between the banking presence in the firms' board of directors and the performance measured by Tobin's Q. This may be due to the fact that banks, as directors, serve their interests rather than the shareholders'. Actually, banks do not act in the shareholders' interests. Similarly, Güner et al. [49], using a sample of US companies, found that the presence of commercial banks in the boards of directors has a negative impact on the market performance (Tobin's Q). Moreover, Mitchell and Walker (2008) on a sample of 2746 Compustat companies during 2002, found that the presence of banks in the boards of directors has a negative impact on the market performance (Tobin's Q). However, Loderer and Peyer [50] found no significant relationship between the banking presence in the board and Tobin's Q.

On the other hand, Lehmann and Weigand [30] showed that there is a positive relationship between the banking presence in the board and performance. Moreover, [19], on a sample of Japanese companies, stated that appointing banks in the boards of directors improves following a low market performance. In addition, the authors found that the firm's performance improves after banks are appointed in the companies' boards of directors. On the other hand, Byrd and Mizruchi [14], by examining a sample of US companies, found that there is a negative relationship between the banking presence in the board of directors and the firms' performance.
Hypothesis 4: The banking presence on the board has a negative impact on the companies' performance (Table 1).

\section{Methodology}

\section{Sample presentation}

The aim of our research is to analyze the impact of the banking presence in the capital and in the firms' boards of directors on their accounting and market performance. For this reason, a sample of 14 listed companies on the Tunis Stock Exchange (TSE) is used. As the sample characteristic, the study examined 14 TSE listed firms on the over a 7-year period from 2003 to 2009, which amounts to 98 observations. In this research, two types of data are taken into account: financial data and data related to the composition of the board and ownership structure. Financial data are collected from companies' financial statements published by the CMF. As for the composition of the board and ownership structure, all the necessary data were collected from the value sheets available within the Tunis stock exchange (TSE). By performing Fisher's test (F-test), it is assumed that our model is either a fixed or random individual effect model. The specification of these effects according to Hausman's test (1968) tells indicates that the models that fit the sample data structure are fixed effect models.

Model, variables and measures: $\operatorname{PERF}_{\text {it }}=\alpha_{0}+\alpha_{1}$ Percent bankers $+\alpha_{2}$ Bankshr $+\alpha_{3}$ TCA $+\alpha_{4}$ LNTA $+a_{5}$ (VentesN-VentesN-1/Ventes $\mathrm{N}-1)+\mu_{\mathrm{t}}$

In order to test the hypotheses related to the impact of the banking presence in the firms' boards of directors and in the ownership structure on performance, econometric estimation techniques on panel data were chosen. Our model is a fixed effect panel data model with PERF the performance measured through the ROE, ROA, Tobin $\mathrm{Q}$ and arris $\alpha_{0 \ldots \ldots \ldots . . .} \alpha_{5:}$ The estimation techniques $\mu_{\mathrm{t}}$ The regression residue.

Variables: The variables used in this study are connected with the board of directors, namely the banks' presence as administrators and the ownership structure, such as the banking participation in the companies' capital. Besides, two other control variables have been included in models, namely the sales growth rate, the company's and the Board's size.

\section{Performance measures}

A/Accounting performance: The ratio of the overall asset returns or the "returns on assets" (ROA)

This ratio is measured by the ratio of the net income to the total assets. It is the return on assets, which generally shows accounting profitability.

\section{-The ratio of net income or "return on equity" (ROE)}

This ratio, which is measured by the ratio of net income to equity, expresses financial profitability. The problem with this ratio is that it can give a distorted picture of profitability since a high ratio may be the result of a low level of funds.

\section{Hypotheses}

$\mathrm{H} 1$ : The relationship between the banking participation in the capital and the firms' performance is pointing upwards (interest convergence hypothesis or interest alignment)

$\mathrm{H} 2$ : The relationship between the banking participation in the capital and the firms' performance is pointing downwards (conflicting interest hypothesis)

H3: The relationship between the bank participation in the capital and the firms' performance falls then rises (managerial hypothesis)

$\mathrm{H} 4$ : The relationship between the banking presence in the companies' boards of directors and performance is negative

Table 1: The banking presence on the board has a negative impact on the companies' performance. 
Citation: Affes H, Hakim NH (2016) Bankers on Board, Banks as Shareholders and Firm's Performance: Case of the Tunisian Listed Companies. J Bus Fin Aff 5: 180. doi:10.4172/2167-0234.1000180

Page 6 of 8

\section{B/The stock market performance: - The Tobin's Q}

We think it is more appropriate to use, besides the accounting measures, a performance measure, such as Tobin's $Q$, which reflects the future. The Tobin's Q reflects the financial market forecasts of future growth and potential profitability of a firm. This ratio is measured by the ratio between the sum of the market values of securities held by financial investors and the amount of capital these investors invested.

The value of the invested capital is measured by the replacement cost of the financial assets. The asset market value is obtained by reducing the book value of the market capitalization debt. In practice, such a measure is difficult to use because of the data unavailability. Therefore, we use a proxy, such as the ratio (market value of equity debt book value) divided by the book value of the total assets.

\section{-The Marris ratio}

The Marris ratio, which is the ratio of the bank market capitalization to equity at the book value, is itself an indicator that reflects the opportunities for growth. When this ratio is greater than 1, the bank creates value; otherwise, it would destroy it (Table 2).

\section{Results and Interpretations}

\section{Descriptive statistics}

The descriptive statistics supplied in this table show that the average performance measured by the ROA is $2.88 \%,-4.95 \%$ for the ROE, $30.62 \%$ for the Tobin Q and 2.2729 for Marris ratio. Since the Marris ratio is above 0.1 , therefore, the company creates value. According to the descriptive statistics, it can be deduced that the banking presence in the capital and in the Board of Directors of the Tunisian companies improves their stock market performance (Tobin Q and MARRI) and decreases their accounting performance measured with the ROA and ROE. The average growth rate of these companies is about $5.67 \%$ and the average company's size measured by the natural logarithm is equal to 11.44 , (that is $92985.607 \mathrm{D}$. This proves that the Tunisian companies in our sample are larger compared to the companies in the study by Byrd DT, Mizruchi [14] of which the natural logarithm of the total assets is of the order of $\$ 4.38179 .9179$ (Table 3).

Regarding the Board of Directors' characteristics, its average size, which is equal to 9.651, has between 5 and 12 members. Therefore, the Tunisian companies apply the standards for the size of their Boards of Directors. This table shows that banks' shareholding (bankshr) is on average $28.09 \%$ whereas their presence in the companies' Board of Directors (percent bankers) is $23.61 \%$. As a consequence, the Tunisian companies apply the standards regarding the participation of the banks in their capital (the Act of July 10, 2001 states that a credit institution may hold more than $30 \%$ in a company).

\section{Correlation matrix}

Impact of the accounting performance: The regression results show that the presence of banks as shareholders has a negative and significant effect on performance, as measured by the ROA, and negative and significant, as measured by the ROE. On the other hand, their presence, as administrators, has a positive and significant effect on these two accounting performance measures. The negative relationship between the banking participation in the Tunisian companies' capital and performance is consistent with the study of [28,31]. This waning relationship is explained by the hypothesis of conflicting interests. Actually, the banking interests do not coincide with the other shareholders' interests. The positive relationship between the banking presence in the Boards of Directors of the Tunisian companies and their performance is explained by the hypothesis of reducing information asymmetries and the agency costs between the shareholders and the creditors. On the other hand, there is a positive relationship between the control variables and the accounting performance measured with

\begin{tabular}{|c|c|c|}
\hline Variables & Significance & Measure \\
\hline \multicolumn{3}{|c|}{ Dependent variables } \\
\hline ROA & Return on Assets & Net profit/Total Assets \\
\hline ROE & Return on Equity & Net profit/shareholders' equity \\
\hline Qt & Tobin Q & Log ((market capitalization + total assets-equity Total Assets \\
\hline $\mathrm{m}$ & Marris Ratio & Equity market value/equity accounting value \\
\hline \multicolumn{3}{|c|}{ Independent variables } \\
\hline $\mathrm{Pb}$ & Banks in the board of directors & The number of banks in the BOD/Size of the Board of Directors \\
\hline Bs & The banking participation in the capital & Capital share held by banks \\
\hline \multicolumn{3}{|c|}{ Control variables } \\
\hline Tc & Sales growth rate & Sales(N) - Sales (N-1)/Sales (N-1) \\
\hline LNTA & Company's size & Natural logarithm/total Assets \\
\hline TCA & Board of directors' size & Overall number of directors \\
\hline
\end{tabular}

Table 2: Variables and measures.

\begin{tabular}{|c|c|c|c|c|c|}
\hline Variable & Obs & Mean & Std. Dev. & Min & Max \\
\hline $\mathrm{ROA}$ & 112 & 0.0288339 & 0.0865126 & -0.2160268 & 0.2408826 \\
\hline ROE & 112 & -0.0495427 & 1.243811 & -12.38258 & 1.69165 \\
\hline qt & 112 & 0.3062448 & 0.4328689 & -1.166932 & 1.539912 \\
\hline $\mathrm{m}$ & 112 & 2.272955 & 2.211723 & -2.207259 & 14.76769 \\
\hline Tc & 112 & 0.0567431 & 0.3087398 & -0.976528 & 1.72802 \\
\hline $\mathrm{Pb}$ & 112 & 0.236104 & 0.1316899 & 0.0833333 & 0.6666667 \\
\hline LNTA & 112 & 11.4402 & 0.9501768 & 9.507106 & 13.41303 \\
\hline bs & 112 & 0.2809241 & 0.1592075 & 0.0189 & 0.622 \\
\hline TCA & 112 & 9.651786 & 2.082574 & 5 & 12 \\
\hline
\end{tabular}

Table 3: Descriptive statistics. 
Citation: Affes H, Hakim NH (2016) Bankers on Board, Banks as Shareholders and Firm's Performance: Case of the Tunisian Listed Companies. J Bus Fin Aff 5: 180. doi:10.4172/2167-0234.1000180

Page 7 of 8

\begin{tabular}{|c|c|c|c|c|c|c|c|c|c|}
\hline & ROA & ROE & qt & m & tc & pb & LNTA & bs & TCA \\
\hline ROA & 1.0000 & & & & & & & & \\
\hline ROE & 0.4376 & 1.0000 & & & & & & & \\
\hline qt & 0.5881 & 0.1378 & 1.0000 & & & & & & \\
\hline $\mathrm{m}$ & 0.4029 & -0.1536 & 0.6833 & 1.0000 & & & & & \\
\hline tc & 0.0827 & 0.1277 & 0.0074 & 0.0004 & 1.0000 & & & & \\
\hline $\mathrm{pb}$ & -0.4987 & -0.1865 & -0.1448 & -0.1172 & 0.2188 & 1.0000 & & & \\
\hline LNTA & -0.1288 & 0.0008 & -0.1241 & 0.0561 & -0.1288 & -0.0111 & 1.0000 & & \\
\hline bs & -0.3785 & -0.1761 & -0.2429 & -0.0708 & 0.1862 & 0.5194 & 0.0407 & 1.0000 & \\
\hline TCA & 0.0289 & -0.0312 & 0.0364 & 0.0455 & -0.2538 & -0.3115 & 0.2674 & -0.1440 & 1.0000 \\
\hline
\end{tabular}

Table 4: Correlation matrix.

\begin{tabular}{|c|c|c|c|c|}
\hline & \multicolumn{2}{|c|}{ Accounting measures } & \multicolumn{2}{|c|}{ Stock market measures } \\
\hline & ROA (Fixe) & ROE (Fixe) & Q de Tobin (Fixe) & Marris (Fixe) \\
\hline Constant & $-0.573043^{* * *}(-2.63)$ & $-2.836517(-0.41)$ & $-2.675348^{*}(-1.74)$ & $-44.17712^{* * *}(-5.20)$ \\
\hline Tc & $0.0254476^{*}(1.98)$ & $0.4819129(1.19)$ & $0.0121155(0.13)$ & $0.1290398(0.26)$ \\
\hline $\mathrm{Pb}$ & $0.1751591^{*}(1.93)$ & $7.080454^{* *}(2.47)$ & $-0.4462486(-0.69)$ & $-7.207806^{* *}(-2.03)$ \\
\hline LNTA & $0.0474531^{* * *}(2.65)$ & $0.1881522(0.33)$ & $0.2997068^{* *}(2.37)$ & $4.144513^{* * *}(5.94)$ \\
\hline Bs & $-0.1346005(-1.59)$ & $-4.841608^{\star}(-1.81)$ & $0.3478799(0.58)$ & $8.233562^{* *}(2.49)$ \\
\hline TCA & $0.055512(0.71)$ & $0.303707(0.12)$ & $-0.4523465(-0.82)$ & $-1.626315(-0.53)$ \\
\hline
\end{tabular}

Table 5: Regressions results of the governance variables by banks (Bank participation in the capital and in the Board of Directors of firms) and the control variables on the performance measures.

the ROA and ROE. This applies particularly to the company's size, that of the Board of Directors and the sales growth rate (Table 4).

Impact on the market performance: The regression results show that the presence of banks, as shareholders, has a positive but insignificant effect on the stock market performance as measured by Tobin's Q and a positive and significant impact measured with the Marris ratio. On the other hand, their presence, as administrators, has a negative and insignificant effect on Tobin $\mathrm{Q}$ and negative and significant impact on the Marris ratio. The positive relationship between the banking participation in the companies' capital and performance is explained by the hypothesis of conflicting or aligned interests. The negative relationship between the banking presence in the firms' boards of directors and their performance is explained by the worsening of agency problems or interest conflicts between the shareholders and the lenders. In fact, the sources of conflict between the lenders and the shareholders are mainly due to the different choices of risk: if the lenders prefer a lower risk, shareholders prefer a higher one. On the other hand, there is a positive relationship between the sales growth rate, the firm's size and the stock market performance. However, the Board of Directors' size has a negative and significant effect on the performance measured by Tobin Q and the Marris ratio (Table 5).

\section{Conclusion}

In this study, we investigated the impact of the banking participation in the capital and in the Board of Directors on the performance of the Tunisian companies. The results show that the Tunisian companies, which apply the standards related to the capital share held by banks (that is $28.09 \%$ against $30 \%$ of the share capital of a company), are characterized by a low presence of banks in their boards of Directors (that is $23.61 \%$ ). Moreover, the results show that the boards of directors of these companies are characterized by a fairly high size.

The Tunisian companies have a poor accounting and stock market performance. The results showed that the effect of the banking presence in their boards of directors is positive and significant for the accounting performance (ROA and ROE), and negative and insignificant for Tobin $\mathrm{Q}$ and negative and significant for the Marris ratio.

\section{References}

1. Morck R, Nakamura M, Shivdasani A (2000) Banks, ownership structure, and firm value in Japan. Journal of business 73: 539-567.

2. Dittmann I, Maug E, Schneider C (2006) Bankers on the boards of German firms: Causes and consequences.

3. Jiang W, Li K, Shao P (2010) When shareholders are creditors: Effects of the simultaneous holding of equity and debt by non-commercial banking institutions. Review of Financial Studies 23: 3595-3637.

4. Randall KS, Strahan PE (1999) Bankers on Boards: Monitoring, Conflicts of Interest, and Lender Liability. Journal of Financial Economics 62: 415-452.

5. Bubna A, Radhakrishnan G (2012) Bank involvement in firm Management Panacea or a Pain? India Finance Conference, IIM Calcutta.

6. Petersen MA, Rajan RG (1994) The benefit of firm-creditor relationships: evidence from small business data. Journal of Finance 49: 3-37.

7. Flath D (1993) Shareholding in the keiretsu, Japan's financial groups. The Review of Economics and Statistics 249-257.

8. Gonzalez F (2006) Banks equity investments: Reducing agency costs or buying undervalued firms? The information effects. Journal of Business Finance and Accounting 33: 284-304.

9. Franks JR, Nyborg KG (1996) Control rights, debt structure, and the loss of private benefits: the case of the U.K. insolvency cod. Review of Financial Studies 9: 1165-1210.

10. Gilson SC, John KL, Larry LHP (1990) Troubled debt restructurings: An empirical study of private reorganization of firms in default. Journal of Financial Economics 27: 315-353.

11. James C (1995) When Do Banks Take Equity in Debt Restructurings? The Review of Financial Studies 8: 1209-1234.

12. Iqbal Z, Shetty S (2002) An investigation of causality between insider transactions and stock returns. Quarterly Review of Economics and Finance 42: 41-57.

13. Berger AN, Udell GF (1995) Relationship lending and lines of credit in smal firm finance. Journal of Business 68: 351-382.

14. Byrd DT, Mizruchi MS (2005) Bankers on the board and the debt ratio of firms Journal of Corporate Finance 11: 129-173. 
Citation: Affes H, Hakim NH (2016) Bankers on Board, Banks as Shareholders and Firm's Performance: Case of the Tunisian Listed Companies. J Bus Fin Aff 5: 180. doi:10.4172/2167-0234.1000180

Page 8 of 8

15. Meckling $J$ (1976) Theory of the firm: Managerial behavior, agency costs and ownership structure. Journal of financial economics 3: 305-360

16. Dewatripont M, Tirole J (1994) The Prudential Regulation of Bank. Cambridge, MA: MIT Press.

17. Rajan RG (1992) Insiders and outsiders: The choice between informed and arm's length debt. Journal of finance 47: 1367-1400.

18. Kang JK, Shivdasani A (1995) Firm Performance, Corporate Governance, and Top Executive Turnover in Japan. Journal of Financial Economics 38: 29-58.

19. Kaplan SN, Minton AB (1994) Appointments of outsiders to Japanese boardsdeterminants and implications for managers. Journal of Financial Economics 36: $225-258$

20. Morck R, Nakamura M (1999) Banks and Corporate Control in Japan. Journa of Finance 54: 319-339.

21. Cable J (1985) Capital market information and industrial performance: The role of West German banks. Economic Journal 95: 118-132.

22. Gorton G, Schmid FA (1996) Universal banks and the performance of German firms. Journal of Financial Economics 58: 29-80.

23. Nibler M (1995) Bank Control and Corporate Performance in Germany: The Evidence. University of Cambridge.

24. Perlitz M, Seger F (1994) The Role of Universal Banks in German Corporate Governance. Business and The Contemporary World 6: 49-67.

25. Seger F (1997) Banken, Erfolg und Finanzierung, Deutscher Universitäts Verlag, Wies-baden.

26. Zoido ME (1998) Un estudio de las participaciones accionariales de los bancos en las empresas españolas. Investigaciones económicas 22: 427-467.

27. Pushner GM (1995) Equity ownership structure, leverage, and productivity: Empirical evidence from Japan. Pacific-Basin Finance Journal 3: 241-255.

28. Weinstein D, Yafeh $Y(1998)$ On the costs of a bank-centered financial system: Evidence from the changing main bank relationships in Japan. Journal of finance 53: 635-672.

29. Gorton G, Schmid F (2000) Universal banking and the performance of German firms. Journal of financial economics 58: $29-80$.

30. Lehmann EE, Weigand J (2000) Does the governed corporations perform better? Governance structures and corporate performance in Germany. European Finance Review 4: 157-195

31. Chirinko SR, Elston JA (2006) Finance, control and profitability: The influence of German banks. Journal of Economic Behavior and organisation 59: 69-88.

32. Kang J, Stulz R (2000) Do banking shocks affect borrowing firm performance? An analysis of the Japanese Experience. Journal of Business 73: 1-23.

33. Emmons WR, Schmid FA (1998) Universal banking, control rights, and corporate finance in Germany. Federal Reserve Bank of St. Louis Review 80 19-42

34. Palenzuela AV, Iturriaga LFJ, Tejerina FG (2008) Banks as shareholders: The Spanish model of corporate governance. Nova Science Publishers pp: 55- 82.

35. Wenlian G (2008) Banks as lenders and shareholders: Evidence from Japan Pacific-Basin Finance Journal 16: 389-410.

36. Nakatani I (1984) The economic role of financial corporate grouping. In Aoki M (Ed), The economic analysis of the Japanese firm, North-Holland: Amsterdam pp: 227-258.

37. Troege M (2000) Should banks be allowed to own equity in non-financial firms? Mimeo Northwestern University.

38. Nachane DM, Ghosh S, Ray P (2005) Bank nominee directors and corporate performance: Micro-evidence for India. Economic and Political Weekly 40: 1216-1223.

39. Edwards J, Nibler M (2000) Corporate Governance in Germany: The Role of Banks and Ownership Concentration. Economic Policy 15: 237-267.

40. Prowse SD (1992) The structure of corporate ownership in Japan. Journal of Finance 47: 1121-40.

41. Rosenstein S, Wyatt JG (1990) Outside directors, board independence, and shareholders wealth. Journal of financial economics 26: 175-191.

42. Mace MLG (1971) Directors: myth and reality. Division of research graduate school of business administration, Havard University, United States.

43. Pfeffer J (1972) Size and composition of corporate boards of directors: The organization and its environment. Administrative Science Quarterly 17: 218-228.

44. Baysinger BD, Butler HN (1985) Corporate governance and the board of directors: Performance effects of changes in board composition. Journal of Law, Economics and Organizations 1: 101-124.

45. Kesner IF (1988) Directors' characteristics and committee membership; An investigation of type, occupation, tenure and gender. Academy of Management Journal 31: 66-84.

46. Naohito A, Noel G, Kastsuyuki K (2005) Executive pay in Japan: the role of bank-appointed monitors and the Main Bank relationship. Japan and the World Economy 17: 371-394

47. Santos JAC, Rumble AS (2004) The American Keiretsu And Universal Banks: Investing ,Voting And Sitting On Non Financials' Corporate Boards. Journal O Financial Economics 80: 419-454.

48. Dittmann I, Maug E, Schneider C (2005) Bankers and the performance of German firms. Working paper.

49. Guner AB, Malmendier U, Tate G (2005) The impact of boards with financia expertise on corporate policies. NBER Working Paper No. 11914.

50. Loderer CF, Peyer U (2001) Board overlap, seat accumulation and share prices. European Financial Management 8: 165-192. 